\title{
Gubeng bridge in Surabaya, a dutch architect c. citroen's work in the 1925 Paris exhibition
}

\author{
Joko Triwinarto Santoso* \\ Department of Architecture, Brawijaya University, 65145 Malang, Indonesia
}

\begin{abstract}
A Dutch architect Cosman Citroen (1881-1935) is recognized as one of the well-known architects in the Netherlands Indies or Indonesia nowadays. After leaving his job as an architect assistant in the architectural firm of B.J. Ouëndag in Amsterdam, the Netherlands, Citroen moved to Surabaya, Indonesia where he became a municipal architect. Here, he turned out to be a versatile architect whose projects range from furniture to town planning and from architectural designs to civil constructions. Discussion on Dutch colonial architecture in this city cannot be separated from his works. One of them was Gubeng Bridge that won an award at the 1925 Paris Exhibition. By using a combination of historical, descriptive, and archival methods, this paper reveals how initially Citroen involved in this civil project, how it was designed and built, which award is obtained, and why it could win the award. The result shows that design of the bridge is in accordance with the exhibition theme, namely Art Deco, and reflects the high aesthetic value of a civil construction.
\end{abstract}

\section{Introduction}

A Dutch architect Cosman Citroen (1881-1935) is recognized as one of the well-known architects in the Netherlands Indies or Indonesia nowadays (Fig. 1). After leaving his job as an architect assistant in the architectural firm of B.J. Ouëndag in Amsterdam, the Netherlands, Citroen moved to Surabaya, Indonesia where he became a municipal architect. He left a lot of works in this city when he is in his position and after his leaving it until his death. His works stretch from furniture design to town planning and from architectural design to construction of civil that are intended for the lower class to the upper-class society, both native and non-native (Dutch, English and Chinese). At the present, his works become historic architectural heritage that could form the townscape of Surabaya. The discourse about architecture in the city will not be separated from Citroen and his works. One of his works is Gubeng Bridge, which is the second civil construction work, after Kebondalem Wood Bridge, out of four projects.

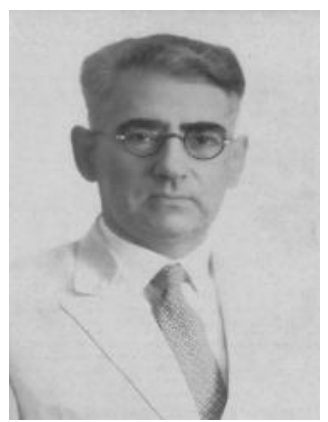

Fig. 1. Cosman Citroen (1881-1935) [1]
Research on the Gubeng Bridge mentioning Citroen won an award in the 1925 Paris Exhibition was only an article written by De Zeeuw in 2001. Most likely, its reference source is an article at Indisch Bouwkundig Tijdschrift - Locale Techniek (IBT-LT) or Indies Architectural Magazine - Local Engineering, written by Heida (1933). But, until now there is no a study that is able to reveal which award is obtained and why it could win. This article will reveal the existence of the Gubeng Bridge from the beginning, starting from the idea to build a new Gubeng Bridge, Citroen involvement, design process, construction, award obtained, until the possible reasons why it could win the award.

\section{Method}

This study was conducted by using a combination of archival, historical, and descriptive methods.

Archives cover Notulen van de Openbare Vergadering van den Gemeenteraad van Soerabaja (Minutes of Public Meetings of the Surabaya City Council), Gemeenteblad van Soerabaja (Municipal Sheet of Surabaya), and old photographs of the Gubeng Bridge. The use of two first archives is based on the premise that involvement of Citroen, as the advisory architect of the Surabaya Municipality, had to be discussed and decided in the meetings of the city council as a legislative institution. All of this discussion is recorded in detail in the form of the minutes of the city council. Furthermore, conclusions and decisions of the city council are stated in a decree of the Surabaya mayor and written on a municipal sheet. Old photographs are used to compare form and details of the bridge in the past and present condition.

Corresponding author: jokotris@yahoo.com, jokotris@ub.ac.id 
The above archives are strengthened by old publications (periodical, report, and book). They comprise Indisch Bouwkundig Tijdschrift (IBT) or Indies Architectural Magazine, which later became IBT-LT, report of Oost Java Stoomtram Maatschappij (East Java Tramway Company), and a book on Surabaya written by G.H. von Faber.

All of textual data is analyzed descriptively based on its content. It consists of diachronic analysis (chronological order or time sequence) and synchronic one (occurring at the same time).

\section{Results and discussion}

\subsection{Idea}

Gubeng Bridge crossed Kali Mas or Mas River (Fig. 2) and connected the Gubeng area and Ketabang, location of a New Surabaya Town Hall, via Simpang Street (now Pemuda Street). The idea was to replace the old bridge (Fig. 3) which was considered to be too narrow [2]. Gubeng Bridge was constructed out of steel which meant that it could not be made wider without having to remove it completely. Gubeng is one of the expansion areas of Surabaya. The Municipality bought the area for the amount of $f 145,000$ in 1908 [2]. Most of the area was used for housing for European. However, the existence of the train station in Gubeng, built by Staatsspoorwegen (SS) or State Railways, made it an important area. Not far to the west of this bridge, there was the old Centrale Burgerlijke Ziekeninrichting (CBZ) or Central Civil Patient Institution as well as Gubeng Sluice in the south (Fig. 4).

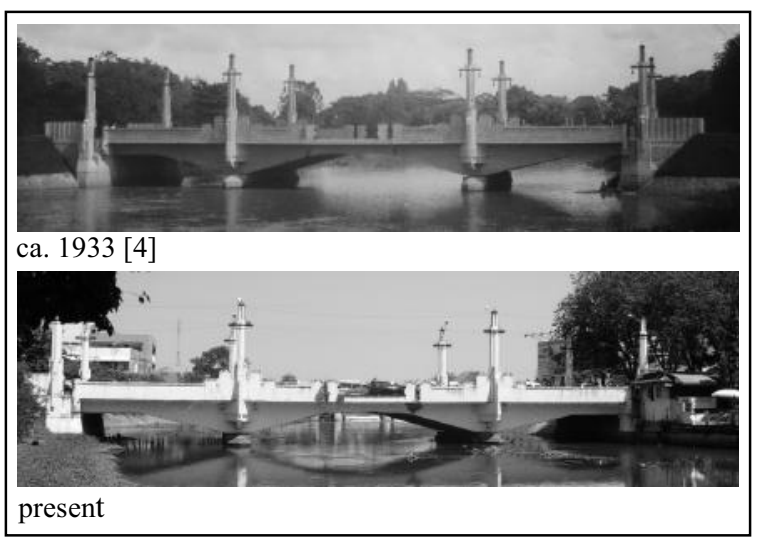

Fig. 2. View from Mas River

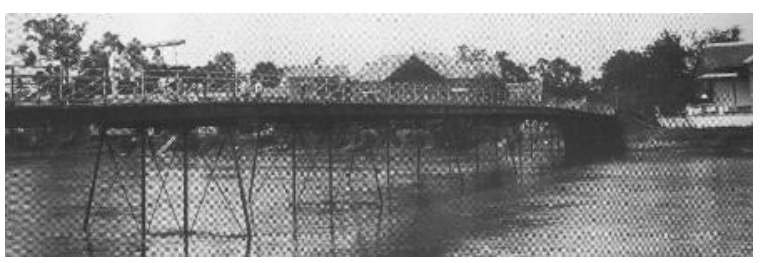

Fig. 3. Old Gubeng Bridge [5]

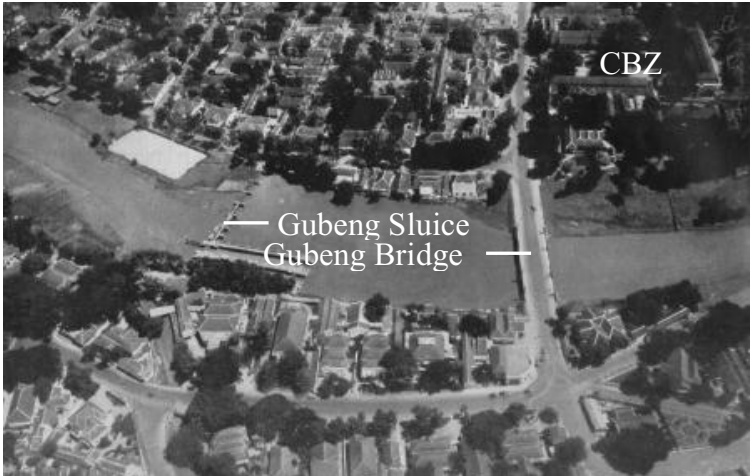

Fig. 4. Bird's-eye view [1]

The decision to build the new bridge was taken at a meeting of the Surabaya City Council on 5 October 1921, led by substitute Mayor Th.B.A. Faubel. All members of the Council accepted the proposal, after which the Municipality declared the proposal accepted in the Gemeenteblad (Municipal Sheet) 1921 number 248. The Municipal Sheet mentioned that the bridge was not only intended for cars and other vehicles, but also for electric trams operated by the Oost-Java Stoomtram Maatschappij (OJS) or East Java Tramway Company [6].

OJS's plan to connect Gubeng to Simpang by an electric tram line had been in preparation since at least 1911. This double track is part of the GubengPalmenlaan route [7]. OJS built a tram stop on a platform of Gubeng Station.

\subsection{Design}

Based on an offer letter of the Director of Dienst van Publieke Werken (Public Work Service) to the Municipality, in 1922 Citroen was commissioned to design the bridge. In this project, he was assisted by engineers of the Public Work Service [1]. Unfortunately, the drawings cannot be found. Het Hoofd van Constructie en Bruggenbouw (the Head of Construction and Bridges) of the SS sent a letter dated 7 February 1923 number $1380 / 455$ to the representative of OJS in Semarang concerning the design made by Citroen. OJS replied to it by sending a letter dated 22 February 1923 number 3568/13 which contained a proposal for design modifications and supplements to be approved by the authorities [8]. The Mayor of Surabaya received a letter concerning the design modifications from the Head of Construction and Bridges of the SS dated 17 September 1923 number 9800/455. The letter informed the Mayor that the modifications were still under consideration, but that the Director of Public Work Service did not have any objections. The technical and financial committees also approved it [8].

The new design was a bridge with a $47.4 \mathrm{~m}$ span, which consisted of one $22 \mathrm{~m}$ free span in the middle and two $13 \mathrm{~m}$ side spans [2], although Von Faber mentions a $22.5 \mathrm{~m}$ middle section and two $13.5 \mathrm{~m}$ side spans [1]. The total width was $16 \mathrm{~m}$ [9], $12 \mathrm{~m}$ for traffic and the rest for two sidewalks on either side. Traffic was divided 
into three lines, one for double electric tram tracks in the centre and two lines for other vehicles [2] (Fig. 5).

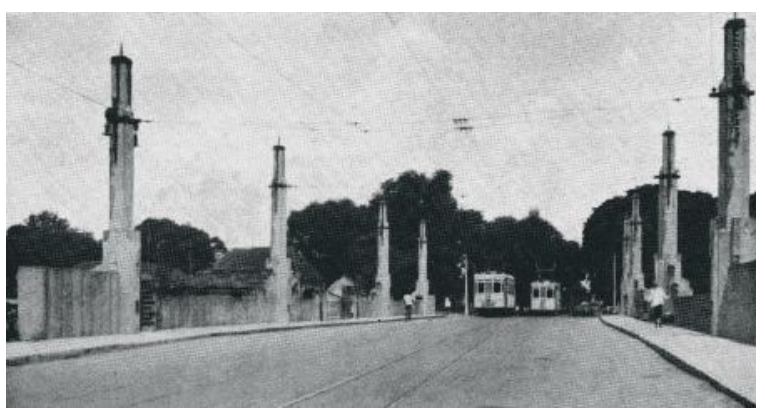

Fig. 5. View from Gubeng Area [2]

The middle part of the railing is more 'transparent' [9]. It is made of iron bars, in contrast to the solid concrete in other parts [2]. The use of iron has the advantage of avoiding cracks in the middle section. There is a difference in the vibration between the middle and side sections because of the dynamic load from the electric trams and other vehicles; the farther the position from the bridge supports, the more substantial the vibration (Fig. 6).

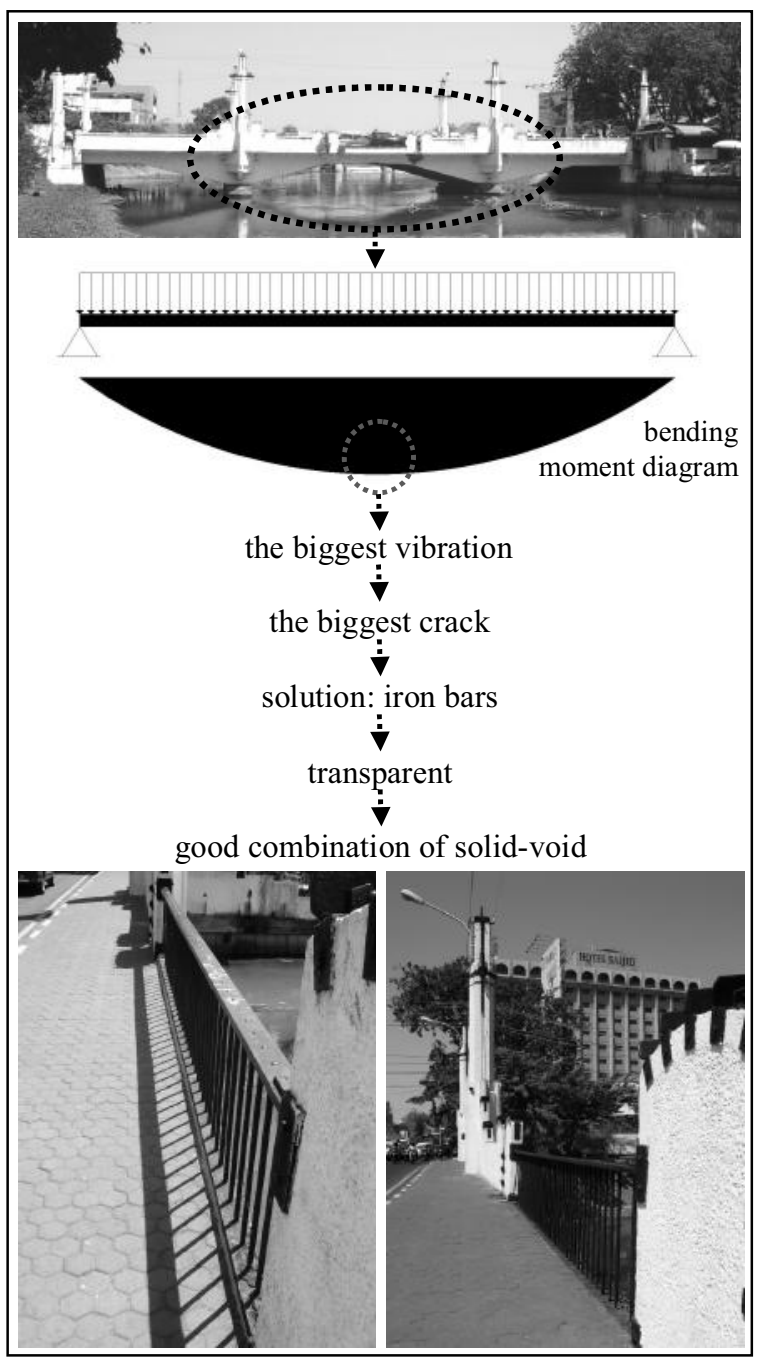

Fig. 6. Railing in the middle part
Several parts made of solid concrete are finished by iron 'fish-fin' or 'fish-scale' ornaments (Fig. 7, Fig. 8, and Fig. 9). Probably, selection of fish as a source of ideas is derived from the name of the city (Surabaya) which comes from Javanese words "sura" (= kind of fish) and "baya" (crocodile). Fish and crocodile are two animals found in the symbol of the city from time to time, both in the Dutch colonial period and in the present (Fig. 10).

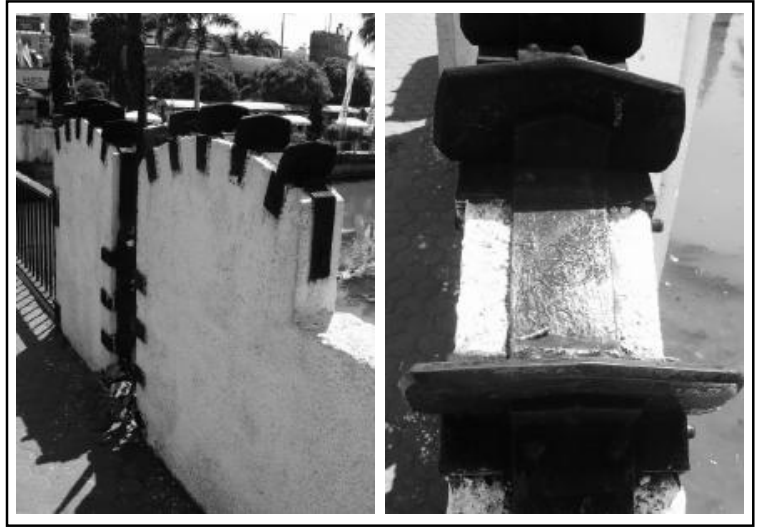

Fig. 7. Iron 'fish-fin' or 'fish-scale' ornaments on the railing

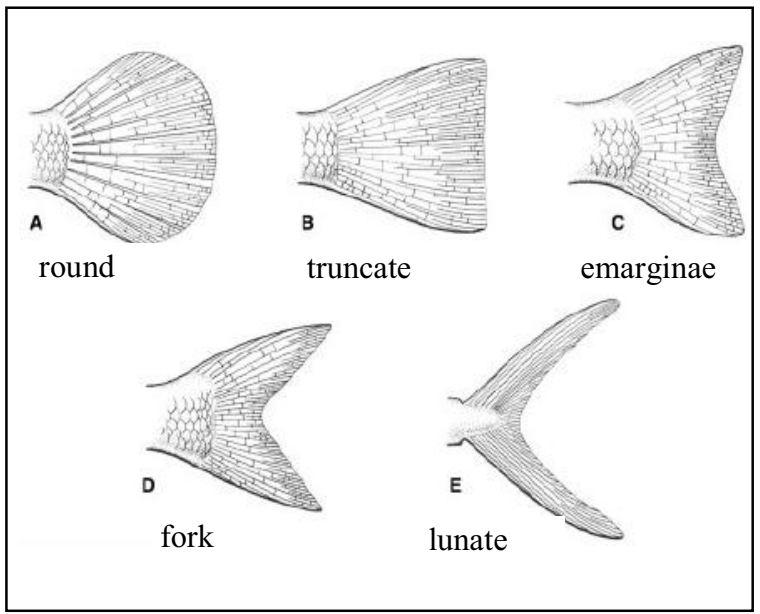

Fig. 8. Fish fin shape [10]

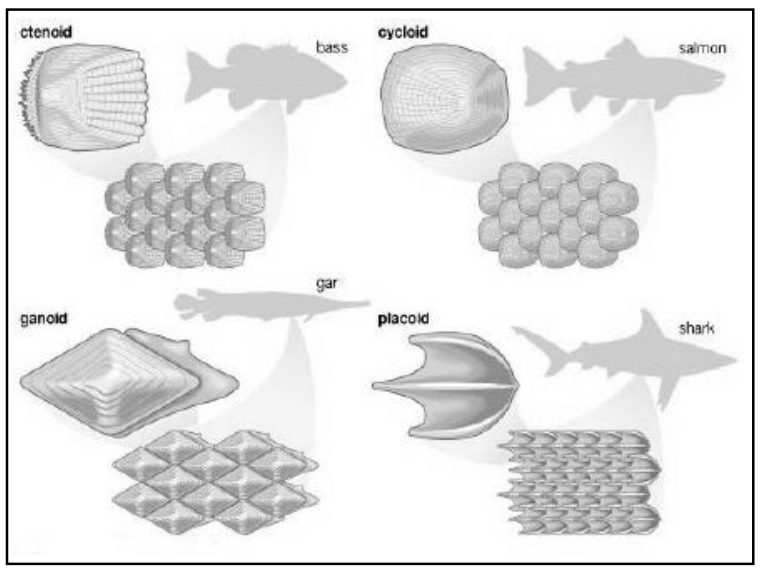

Fig. 9. Fish scale shape [11] 


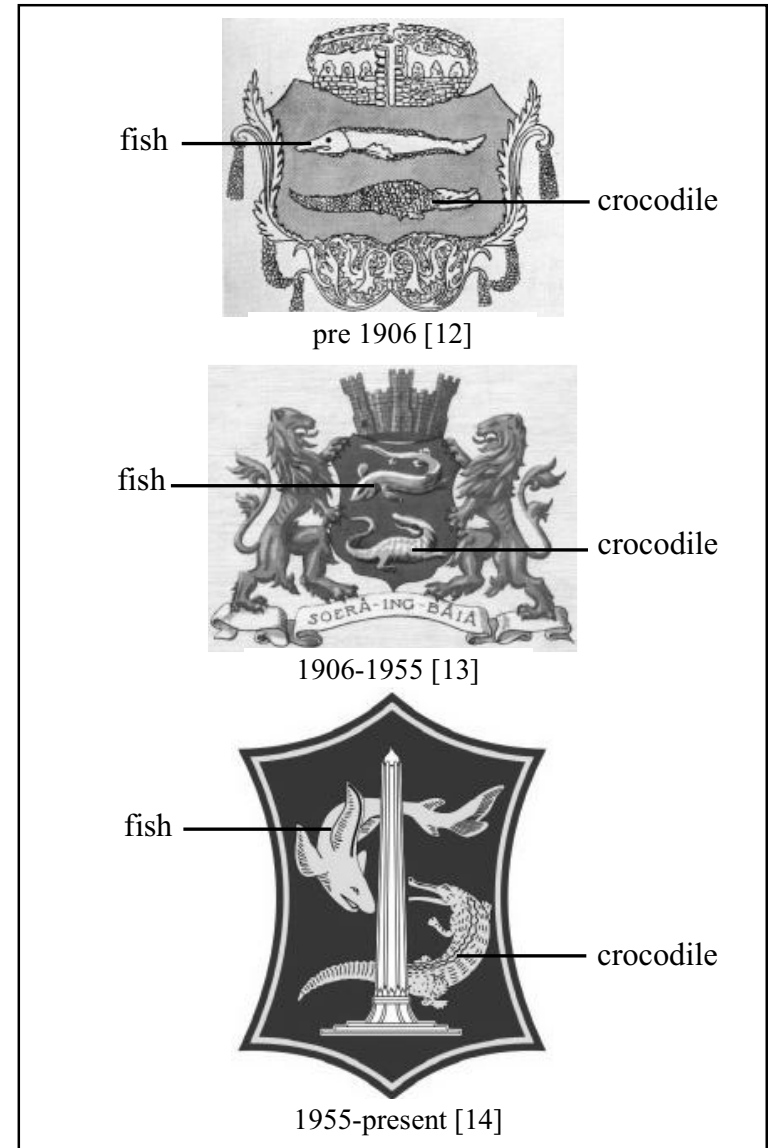

Fig. 10. Symbol of Surabaya City

The railing also features cylinders with pointed iron tips (Fig. 11), similar to the same elements in the Surabaya Town Hall, and a short iron 'spear' ornament (Fig. 12). The electric wire is attached to eight tall lamp posts [2] (Fig. 13). The top of each post has iron ornaments (Fig. 14), the form of which is also similar to ornaments in the town hall. Besides being aesthetic elements, these ornaments function as hooks for electric wires and street lamps. The positioning of the posts echoes the position of the supports of the bridge beams (Fig. 15).

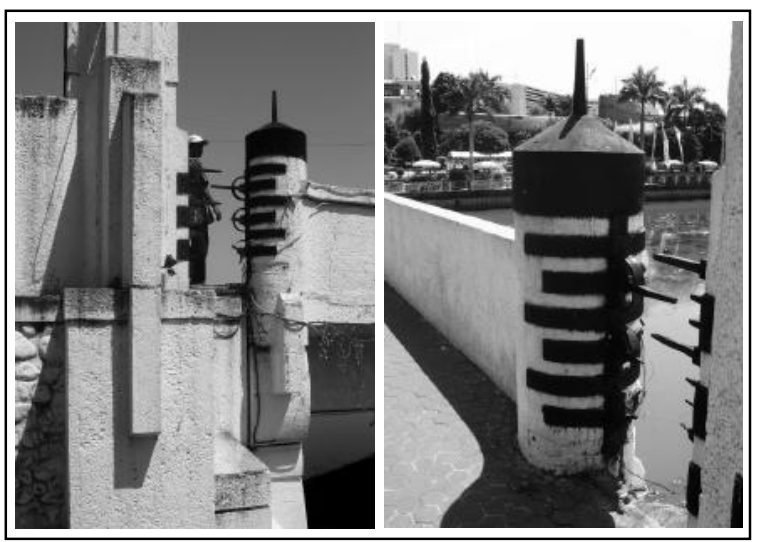

Fig. 11. Iron ornaments on the railing and bottom part of a lamp post

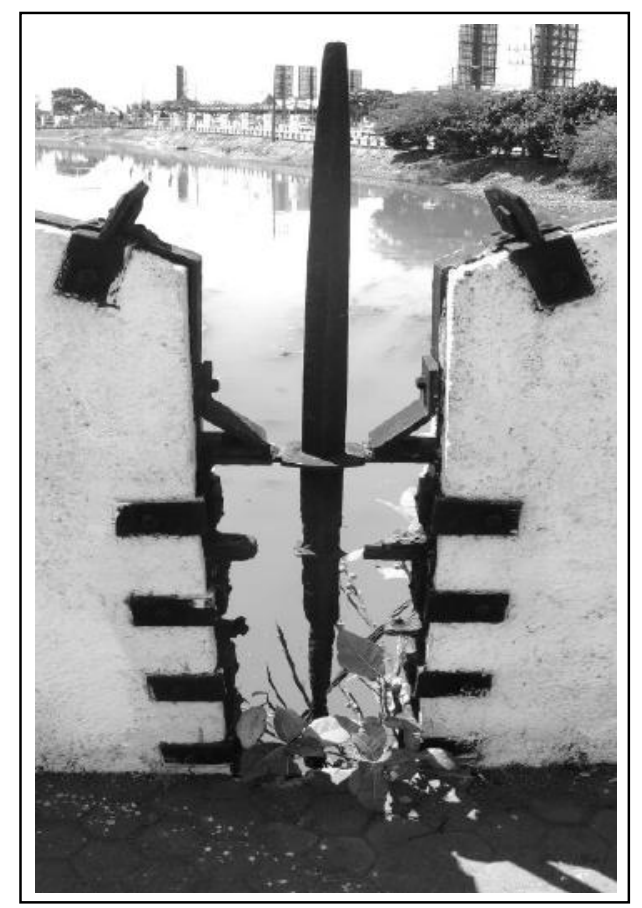

Fig. 12. Iron 'spear' ornament on the railing

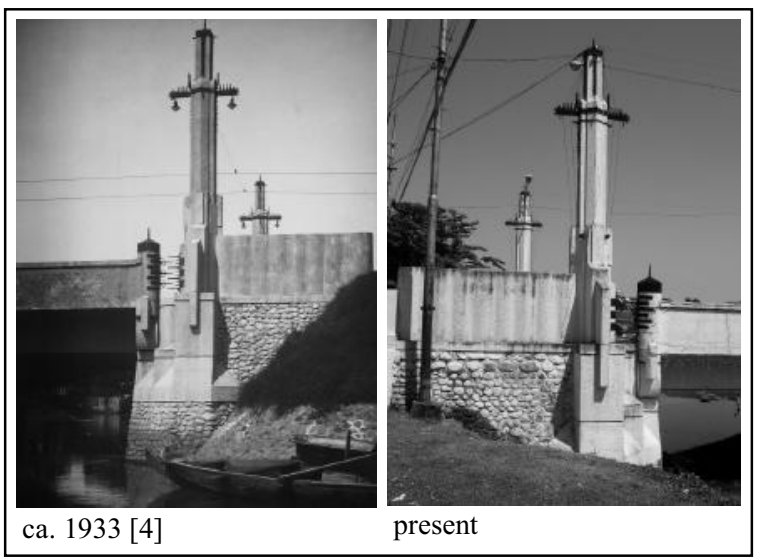

Fig. 13. The lamp post

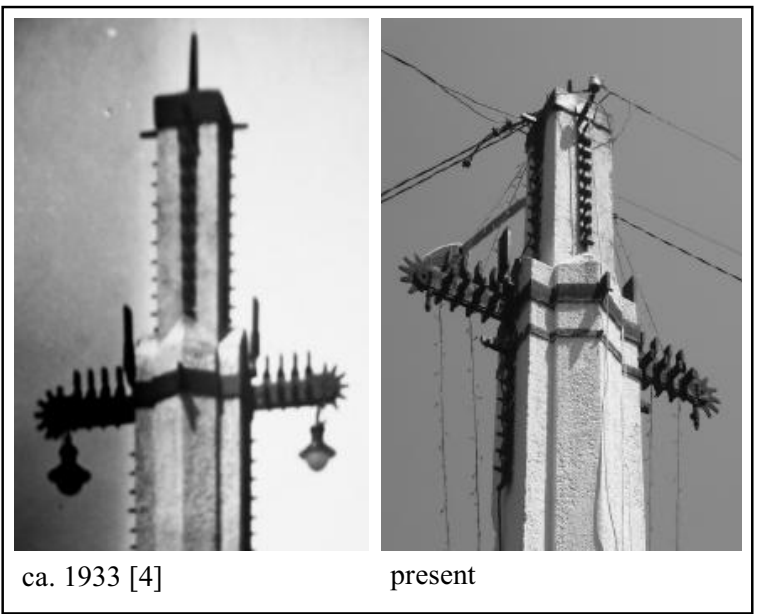

Fig. 14. Upper part of the lamp post 


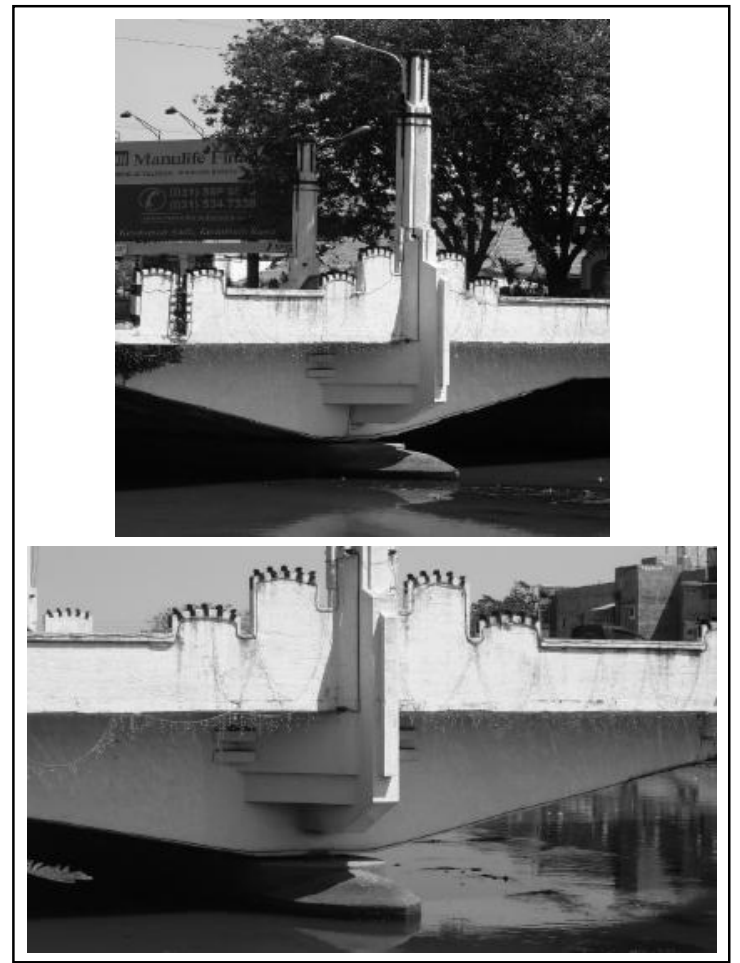

Fig. 15. The lamp post and middle pillar

The bridge's upper structure was made of reinforced concrete using the Gerber beam principle. The height of the beam in the middle section is only $90 \mathrm{~cm}$, in order to allow boats to pass through. The maximum thickness or height of the beams is $2.90 \mathrm{~m}$ and the width is $35 \mathrm{~cm}$. Each beam holds 13 steel bars, each 1.25 " in diameter size. Each part of the foundation of the bridge has two 14 $\mathrm{m}$ wood piles, each of which is able to carry a maximum load of 12 tons. The thickness of the plate is $12 \mathrm{~cm}$ [2].

\subsection{Cost and construction}

After the municipality and the city council agreed to the proposal to build the bridge, and the design was finished by Citroen, the Director of Public Work Service sent a letter offering the total budget for building the new Gubeng bridge for the amount of $f$ 254,000. OJS contributed $f 115,000$ to this budget. Furthermore, the municipality collected $f 15,000$ from the sale of iron or steel from the old bridge. At least another $f$ 5,000 was raised from the sale of the wood used for the formwork (bekisting) of the reinforced concrete and a temporary dam. Thus, the municipality only raised $f 119,000$. This figure was included in the budget of 1923 point XIX B 202. The financial committee had approved the design and its budget, while recommendations from the technical committee would be delivered soon [15].

Based on the Municipal Sheet number 280 dated 19 December 1922, the bid for the construction work was ready to be held and the invitation would be announced publicly. No information can be found on the bidders. However, it is clear that the Nederlandsche Aanneming Maatschappij (Nedam) built the bridge in 1923-1924 [1].

\subsection{Gubeng Bridge at the 1925 Paris exhibition and its award}

In the design of the Gubeng Bridge Citroen shows his competence as an architect who is able to successfully combine aesthetic aspects and constructional considerations. Although he is helped by engineers from the Public Work Service, Citroen still plays an important role in the creation of a pleasing appearance for the bridge, so that it is not only strong enough to carry the traffic load (trams, cars, and other vehicles) but also represents a beautiful element of the urban infrastructure. He creates a harmonious blend between the solidity of concrete and the transparency of the iron balustrades, reflecting mechanical principles. An Amsterdam School touch is found in the iron details of the bridge, while the design of the concrete lamp posts tends to be in Art Deco style. Citroen was able to amalgamate different styles and materials in a harmonious composition. This is probably the reason why the design won an award at the 1925 Paris Exhibition. As we know, the 1920s were the period of Art Deco, expressed profusely in the 1925 International Paris Exhibition.

The International Paris Exhibition, opening on 28 April 1925 and closing in October 1925 with the theme "Exposition Internationale des Arts Décoratifs et Industriels Modernes" (International Exhibition of Modern Decorative and Industrial Arts) was the (international) exhibition where Citroen's works were showcased for the first time. His design was dedicated to the display of modern decorative arts. The exhibition brought together thousands of designs from all over Europe and beyond with over 16 million visitors attending. The exhibition was shaped by France's ambitions in the years immediately following the First World War. Its aim was to establish the preeminence of French taste and luxury goods. French displays dominated the exhibition, and Paris was presented as the most fashionable of cities [16].

J. de Bie Leuveling Tjeenk, Commissioner-General of the Dutch department at the exhibition, made it known that the Dutch Pavilion presented the works of 237 artists and designers, who were classified into nine groups: architecture, interior and furniture; sculpture and small plastic construction; wall decoration; stained glass and mosaic; textile; ceramics and glassware; processed metal and jewellery; book and print art; and applied graphics [17]. The Dutch pavilion received the special attention which was demonstrated by a letter of the president of the jury, Pontrémolly, to the CommissionerGeneral [18].

The Netherlands Indies, as a part of the Dutch pavilion, were represented by architect J.H. Antonisse, J.F.L. Blankenberg, C. Citroen, B.J.K. Cramer, J. van Hoytema, the Hulswit-Fermont-Ed. Cuypers architectural firm, the Karsten-Lutjens-Toussaint architectural firm, H. Maclaine Pont, and P.A.J. Moojen [17]. Among them, only Blankenberg, Citroen, and the Karsten-Lutjens-Toussaint firm were able to achieve an award in the exhibition. The two first earned a "Mention", the lowest category of awards, while the firm of Karsten-Lutjens-Toussaint got a bronze medal. 
Citroen obtained the award for his design of the Gubeng Bridge [18].

\section{Conclusion}

Gubeng Bridge is a Dutch architect C. Citroen's civil construction work that has a touch of aesthetics, in addition to a structural aspect. The aesthetic touch here is a blend of Art Deco and Amsterdam School style. Art Deco itself was the architectural style which was popular in the 1920s and became the theme of the 1925 Paris Exhibition. Thus, the bridge reflects the high aesthetic value of a civil construction. That is why the bridge won the Mention award in the event.

\section{References}

1. G.H. von Faber. Nieuw Soerabaia, (H. van Ingen, Soerabaia, 1934).

2. R. Heida. Bruggenbouw in Indische Steden. IBT-LT, 2(2), 5-12 (1933).

3. Handinoto. Perkembangan Kota dan Arsitektur Kolonial Belanda di Surabaya 1870-1940, (Andi, Yogyakarta, 1996).

4. Nederlands Architectuurinstituut, archive, (Rotterdam, 1935).

5. G.H. Bartman. Fotografien van Soerabaja, (Thomas \& Eras, 's-Gravenhage, 1975).

6. Gemeente Soerabaja. Notulen der Openbare Vergadering van den Gemeenteraad van Soerabaja, 349-352 (5 October 1921).
7. W.H. Trom. Rapport Betreffende de Electrificatie der Stadslijnen der Oost Java Stoomtram Maatschappij te Soerabaia, (Nederlandsch Indische Tram Mij., Batavia, 1911).

8. Gemeente Soerabaja. Gemeenteblad van Soerabaja, 265, 911-913 (14 November 1923).

9. Wouter de Zeeuw. Cosman Citroen 1881-1935, typescript, (Nederlands Architectuurinstituut, Rotterdam, 2001).

10. Thomson Higher Education, (2007). Figure on: http://rodnbarrel.com/post/149743956200/fisharchitecture-caudal-fins

11. Encyclopædia Britannica, (2009). Figure on: https://www.britannica.com/ science/scale-zoology

12. Nanang Purwono. Mana Soerabaia Koe, (Pustaka Eureka, Surabaya, 2006).

13. Hein Buitenweg. Krokodillenstad, (Servire B.V, Katwijk aan Zee, 1980).

14. Lambang Kota Surabaya, (2014). Figure on: http://blog.yoshikanji.web.id/2014/08/lambang-kotasurabaya.html

15. Gemeente Soerabaja. Gemeenteblad van Soerabaja, 280, 1095-1097 (19 December 1922).

16. Victoria and Albert Museum. Art Deco: The 1925 Paris Exhibition. Information on: http://www.vam.ac.uk/content/articles/a/the-1925paris-exhibition/

17. Anonymous. De Internationale Architectuur Tentoonstelling te Parijs in 1925, IBT, 28(12), 146147 (June 1925).

18. Anonymous. Onderscheidingen op de Internationale Architectuurtentoonstelling te Parijs, IBT, 28(23), 262 (December 1925). 